\title{
化学修飾トリプシン由来自己消化断片ペプチドの スペクトルライブラリーを利用したタンパク質の同定
}

\author{
A Strategy for Protein Identification by Using Spectral Libraries \\ of Chemically Modified Trypsin Autolysis Peptide Fragments
}

\author{
吉野健一 $1,2, *$ ・宇佐見 至 $^{3} \cdot$ 竹内敦子 4 \\ Ken-ichi Yoshino ${ }^{1,2}$, Itaru Usami ${ }^{3}$, and Atsuko TAKeuchi ${ }^{4}$ \\ 1 神戸大学バイオシグナル総合研究センター Biosignal Research Center, Kobe University \\ 2 神戸大学大学院医学研究科質量分析総合センター The Integrated Center for Mass Spectrometry, Graduate \\ School of Medicine, Kobe University \\ 3マトリックスサイエンス株式会社 Matrix Science K. K. \\ 4 神戸薬科大学中央分析室 Instrumental Analysis Center, Kobe Pharmaceutical University
}

\begin{abstract}
Chemically modified trypsin by reductive methylation is a standard reagent for identifying proteins by mass spectrometry. The reductive methylation of trypsin is assumed to protect the enzyme against autolysis. However, it has been reported that peptides with mono- or di-methylated Lys, or Asn residues at their C-termini have been observed in autolysis products of chemically modified trypsin. In most cases, the chemical modification of trypsin is not taken into consideration in database searches for protein identification. Spectral data derived from autolysis peptides of chemically modified trypsin might be incorrectly assigned to peptides derived from other proteins, thus creating false-positive identifications. In this paper, we propose a simple strategy for searching databases by using spectral libraries to identify autolysis peptides from heavily chemically modified trypsin, which cannot be identified by a normal search strategy.
\end{abstract}

(Received November 25, 2020; Accepted December 14, 2020)

\section{1. 序論}

ペプチド鎖中の Lys 残基およびArg残基のカルボキシル 基側ペプチド結合（Lys-X, Arg-X）の加水分解を触媒する トリプシン（Trypsin, EC 3.4.21.4）は, トップダウンプロ テオミクスにおいて, 試料タンパク質断片化のための残基 特異的エンドペプチダーゼとして最も高頻度で使用されて (る ${ }^{1) \sim 3)}$. トリプシン分子自身もタンパク質であり，そ のポリペプチド鎖中にはLys-X, Arg-Xのペプチド結合が複 数存在している. そのため試料タンパク質断片化の過程に おいて, トリプシン分子ポリペプチド鎖の断片化，いわゆ る自己消化を避けることはできない( ${ }^{4)}$ ８）．特にゲル内消 化では, 試料タンパク質に比べて大過剩量のトリプシンが 用いられることから, 分析試料中にトリプシン自己消化物 由来の断片ペプチドが豊富に存在している。

自己消化を軽減させるためにトリプシンの Lys 残基にメ チル化注1)等の化学修飾を施した商品が開発され, 市販さ れている注2).しかし，Arg残基に修飾は施されておらず， ペプチド鎖中のすべての Lys残基がメチル化されているわ けではない.したがって化学修飾トリプシンを用いたとし ても自己消化を完全に防ぐことはできない5) 8).

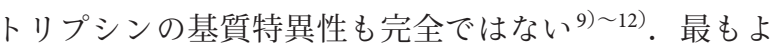

*連絡先：kyoshino@kobe-u.ac.jp
く知られている非特異的な切断はAsn-Xの加水分解であ る.Asn-X以外にも，膵臓から調製品であれば精製の過程 で完全に除去しきれていないキモトリプシンの影響が残さ れている，残存キモトリプシンを不活性化させるために TPCK (L-1-tosylamido-2-phenylethylchloromecthyl ketone) 処理が施されてはいるが，Lys-XやArg-Xと比較すると反 応速度は遅いながらもキモトリプシン様の非特異的な加水 分解が起こることが知られている．驚くべきことは，自己 消化を防ぐために施されたモノメチル化Lys残基やジメチ ル化Lys残基のC末端側のペプチド結合が加水分解される ことによって生じた自己消化断片ペプチドも存在してい $3^{6) \sim 8)}$. 化学修飾トリプシンの自己消化断片ペプチドは, 非特異的な加水分解によって生じた断片ペプチドに加え, モノメチル化やジメチル化の化学修飾を含む断片ペプチド など多様な修飾基を有した自己消化断片ペプチドが存在し ている，本論文では，一般的なデータベース検索条件では

注1） アミノ基の水素原子にメチル基が置換する化学修飾と してモノメチル化，ジメチル化，トリメチル化があるが，本 稿ではこれらの総称として「メチル化」の用語を使用し，具 体的な修飾を示す場合はモノメチル化，ジメチル化と明記す る。ただし MASCOTの modificationの選択肢では “methyl” は monomethylを指す用語として使用されていることから， MASCOTの modificationの選択肢を表記する場合に限って “methyl”はモノメチル (monomethyl) を示す.

注2）市販されている化学修飾トリプシンは必ずしもメチル 化による修飾とは限らない。 
同定できないLys-X, Arg-X以外の非特異的な加水分解に よって生じた断片ペプチドやデータベース検索時に考慮さ れることが少ない化学修飾を含む断片ペプチドを以下「想 定外自己消化断片ペプチド」と表記する.

想定外自己消化断片ペプチドは, 特異的な加水分解に よって生じた自己消化断片ペプチドに比べれば量的には少 量である。試料タンパク質量に比べ, 消化酵素であるトリ プシンの量が少ない場合は想定外自己消化断片ペプチドの 存在は大きな問題にはならない. しかし, プロテオミクス 用の試料, 特にゲル内消化によって調製される試料では, 試料タンパク質に比べてトリプシンは過剩量存在してお り，想定外自己消化断片ペプチドは，タンパク質を同定す るための試料由来のペプチドの分子数と同程度もしくはそ れ以上の量が質量分析計に導入されることもある。その結 果, 想定外自己消化断片ペプチドに由来するプロダクトイ オンスペクトルデータが大量に取得されることになる.

トップダウンプロテオミクスにおいて, タンパク質を同 定するために行われるデータベース検索では, 存在してい るすべてのタンパク質の配列データに対して，すべての修 飾基の存在を想定して検索が行われるわけではない. 分析 担当者が設定した検索条件に合致したアミノ酸配列と修飾 基の情報を満たす母集団の中から，スペクトルデータと合 致する最も可能性の高い候補を示しているに過ぎない.し たがって, 当該スペクトルデータを与えたペプチドのアミ ノ酸配列と修飾基の情報が検索対象となる母集団に含まれ ない検索条件が設定された場合, 母集団の中から相対的に 最も合致している候補が示されることになり, 結果として 擬陽性のアミノ酸配列が提示されることになる。擬陽性の アミノ酸配列であったとしても, 有意な期待值やスコアを 伴って提示された場合, 擬陽性であることに気付くことは 困難である。

化学修飾トリプシンに由来する想定外自己消化断片ペプ チドを同定できない検索条件を用いた場合, 取得された想 定外自己消化断片ペプチド由来のスペクトルデータが異な るタンパク質由来のペプチドとして䛊同定されることは否 定できない，質量確度の高い質量分析計を用いた場合，プ リカーサーイオンの測定質量データによって検索対象とな るアミノ酸配列の候補はかなり限定されるため, 誤同定さ れる確率はそれほど高くはないが, ゼロではない，例え ば，ジメチルLys残基をC末端にもち， $C^{117} と C^{124}$ がS-カ ルバミドメチル化されたブタトリプシンの自己消化断片ペ プチドSCAAAGTECLISGWGNTK (116-133) は, human Ras-related protein Rab-32（RAB32_HUMAN）のN末端ペ プチドに誤同定されることが知られている7),注3).

䛊同定を防ぐために想定外自己消化断片ペプチドをもれ なく同定させるためには, 検索時に設定する消化酵素の特 異性を考慮せず，すべてのぺプチド結合を切断することを

注3）本稿で表記するブタトリプシンのアミノ酸残基番号は, プロペプチドを含んだ前駆体のアミノ酸配列で，SwissProt 等の配列データベースに収録されているUniProtKB P00761 （TRYP_PIG）の配列データに準拠している.
想定する設定（MASCOTでは“none”）にする必要があ り，修飾基として少なくともLys残基のモノメチル化とジ メチル化を考慮する（MASCOTでは “Variable modification”として $[\operatorname{methyl}(\mathrm{K})] と[\operatorname{dimethyl}(\mathrm{K})]$ を選択）必 要がある。しかし，このような網羅的な検索条件は，検索 対象となるアミノ酸配列候補の母集団（search space）を 拡張させてしまうことから，検索時間が長くなることに加 え，䛊ったアミノ酸配列が偶然にマッチする確率を上昇さ せてしまうため, 有意となる期待值の閾值 (significant threshold）をより厳しくする必要が生じる。その結果，通 常の条件で同定可能なタンパク質が同定されなくなるおそ れも生じるため, この方法は通常のプロテオミクスで利用 できる現実的な解決法ではない.

われわれは，一般的に用いられる最適な検索条件をほと んど変えることなく, ほぼ同程度の検索時間で, 簡便に化 学修飾トリプシンに由来する想定外自己消化断片ぺプチド を同定し，想定外自己消化断片ペプチドが䛊同定されるこ とを防止するための方法として，想定外自己消化断片ぺプ チドのスペクトルライブラリーを利用したライブラリー サーチを併用する方法を提案する。

\section{2. 実験}

\section{1 試薬}

試料調製の際に使用する蒸留水は富士フイルム和光純薬 (大阪市) ・高速液体クロマトグラフ用を，アセトニトリル およびトリフルオロ酶酸（trifluoroacetic acid: TFA）はナ カライテスク (京都市) ・高速液体クロマトグラフ用を用 いた. ジチオスレイトールはナカライテスク・SH基タン パク質研究用を, 炭酸水素アンモニウムおよびヨードアセ トアミドは富士フイルム和光純薬・プロテオミクス用を使 用した。

液体クロマトグラフィータンデム質量分析（liquid chromatography/mass spectrometry/mass spectrometry: LC/MS/ MS）の移動相に用いるアセトニトリルおよび超純水は富 士フイルム和光純薬・LC/MS用を，ギ酸はナカライテス ク・カラムクロマトグラフ用を使用した.

化学修飾トリプシンはメチル化処理が施されている Sequence Grade Modified Trypsin（V511A, Promega Corporation, Madison, WI, USA）を用いた。

\section{2 化学修飾トリプシン自己消化断片ペプチド試料の 調製}

トリプシン凍結乾燥品 $20 \mu \mathrm{g}$ が入ったバイアルに $25 \mathrm{mM}$ 炭酸水素アンモニウム溶液 $1 \mathrm{~mL}$ を加え溶解し, $37^{\circ} \mathrm{C}$ で 2 時間インキュベートした． $0.2 \%$ TFA 溶液 $1 \mathrm{~mL}$ を加える ことによって反応を停止させた。減圧濃縮用遠心機を用い て溶液を除いた後， $2 \%$ ア トニトリル $0.1 \% \mathrm{TFA}$ 溶液 $1 \mathrm{~mL}$ に溶解し，その $2 \mu \mathrm{L}$ （トリプシン $40 \mathrm{ng}$ 相当）を LC/ MS/MSに供しデータを取得した.

\section{3 ゲル内消化}

脱色後のゲル片が入った $1.5 \mathrm{~mL}$ のマイクロチューブに 蒸留水 $1 \mathrm{~mL}$ を加え, ThermoMixer ${ }^{\circledR}$ (Eppendorf AG, Ham- 
burg, Germany）を用いて10分間室温で振とう（900 rpm） することによってゲル片の洗浄を行った．蒸留水を交換し， この操作をさらに 2 度行った. 蒸留水を除去し, アセトニ トリル $0.5 \mathrm{~mL}$ を加え, 10 分間室温で振とう（900 rpm）し た.ゲル片が白く縮んだことを確認した後, チューブ内の アセトニトリルを除去した.

白く縮んだゲル片が入ったチューブに $10 \mathrm{mM}$ ジチオス レイトール/25 mM炭酸水素アンモニウム溶液 $200 \mu \mathrm{L}$ 加 え, ThermoMixer ${ }^{\circledR}$ を用いて $50^{\circ} \mathrm{C} て ゙ 1$ 時間振とうすること によってゲル内還元処理を行った。溶液を除去した後, $100 \mathrm{mM}$ ヨードアセトアミド/50 mM炭酸水素アンモニウム 溶液を $200 \mu \mathrm{L}$ を加え, 室温にて 45 分間遮光状態で静置し, ゲル内アルキル化（S-カルバミドメチル化）処理を行っ た.その後, ゲル片が入った $1.5 \mathrm{~mL}$ のマイクロチューブに 蒸留水 $1 \mathrm{~mL}$ を加え, ThermoMixer ${ }^{\circledR}$ を用いて 3 分間室温で 振とう（900 rpm）することによってゲル片の洗浄を行っ た. 蒸留水を交換し, この操作をさらに2 度行った. 蒸留 水を除去し，アセトニトリル $0.5 \mathrm{~mL}$ 加え，10分間室温 で振とう（900 rpm）した.ゲル片が白く縮んだことを確 認した後, チューブ内のアセトニトリルを除去した。

次に化学修飾トリプシンが $20 \mu \mathrm{g}$ 入ったバイアルに $1 \mathrm{~mL}$ の $25 \mathrm{mM}$ 炭酸水素アンモニウム溶液を加えることによっ て調製した酵素溶液を各チューブに $10 \mu \mathrm{L}$ 加えた。ゲルが

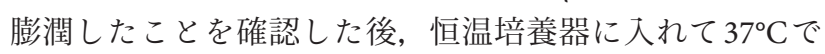
15 時間静置し, ゲル内消化を行った.

\section{4 ペプチドの抽出}

ギ酸溶液（ $0.2 \%, v / \mathrm{v} ） 25 \mu \mathrm{L}$ をチーブに添加すること によって酵素反応を停止させた. $10 \mathrm{~min}$ 室温で静置した あと， $50 \%$ アセトニトリル $/ 0.1 \%$ ギ酸溶液 $25 \mu \mathrm{L}$ をュー ブに加えた. $10 \mathrm{~min}$ 室温で静置した後, チューブ内の溶 液を低吸着仕様の $1.5 \mathrm{~mL}$ チューブに回収した. 次にアセ トニトリル $50 \mu \mathrm{L}$ をチーブに添加し, ゲル片が白く縮ん だことを確認した後, チューブ内のアセトニトリルを回収 し，先に回収した同じ低吸着仕様の $1.5 \mathrm{~mL}$ チューブに加 えた。減圧濃縮用遠心機を用いて溶液を除いた後，2\%ア セトニトリル0.1\% TFA 溶液 $25 \mu \mathrm{L}$ に溶解し, LC/MS/MSに 供した。

\section{5 液体クロマトグラフィータンデム質量分析（LC/ MS/MS)}

液体クロマトグラフィーはDionex UltiMate 3000（Thermo Fisher Scientific, Waltham, MA, USA）を用い, 以下の 条件で行った.

カラム：化学物質評価研究機構(埼玉県北葛飾郡) L-column Micro C-18, 0.1 mm i.d. × $150 \mathrm{~mm}$, 粒径 $3 \mu \mathrm{m}$ カラム温度 : 室温

移動相：アセトニトリル $0.1 \%$ ギ酸系移動相によるリニ アグラジエント

移動相 $\mathrm{A} ： 0.1 \%(\mathrm{v} / \mathrm{v})$ ギ酸水溶液（ギ酸：超純水= $1: 1000)$

移動相 B：0.1\%（v/v）ギ酸アセトニトリル（ギ酸：ア セトニトリル $=1: 1000)$
グラジエント条件：移動相 B 濃度 3-33\%（1\%/min） 流速：UltiMate 3000 から $0.14 \mathrm{~mL} / \mathrm{min}$ で送液された移動 相をスプリットし，カラムでの流速は約 $500 \mathrm{~nL} / \mathrm{min}$ で 行った.

質量分析は, リニアイオントラップ電場型フーリエ変換 (オービトラップ) 質量分析計LTQ Orbitrap Discovery mass spectrometer (Thermo Fisher Scientific, Bremen, Germany）を用い, 以下の条件で分析を行った.

イオン化法：カラムの出口にFortisTip ${ }^{\mathrm{TM}}$ (オムニセパ 口適塾, 尼崎市) を装着し, ポジティブモードのナノフ ローエレクトロスプレーイオン化法によってイオン化を 行った.

キャピラリー電圧 : $1.8 \mathrm{kV}$

測定範囲 $: m / z 300 \sim 1,500$

MS/MS（プロダクトイオン分析）は各スペクトルにお いて上位7番目までの信号強度を示すイオンをプリカー サーイオンとして自動的に選択するデータ依存取得を行っ た.

質量較正は Polytyrosine（1, 3, 6) を用いた外部標準法で 実施した後, ロックマス機能によってスペクトル毎に補正 を行った.

\section{6 データベース検索}

データベース検索とスペクトルライブラリーの作成は MASCOT（http://www.matrixscience.com）Ver. 2.7.0を利用 して行った.

Raw dataから mgfファイルへの変換はProteoWizard (http://proteowizard.sourceforge.net) Ver. 3.0.20266を利用 した ${ }^{13)}$.

SwissProtは2020_05版, common Repository of Adventitious Proteins (cRAP; https://www.thegpm.org/crap) は20190305 版, PRIDE_Contaminants ${ }^{14)}$ は20160906版を利用した。

\section{3. 結果}

\section{1 化学修飾トリプシン修飾基の解析}

Fig. 1に本研究において提案するスペクトルライブラ リーを併用したデータベース検索法のスキームを示す.

「2. 実験」に記載した方法を用いて化学修飾トリプシン から自己消化断片ペプチドの試料を調製し，そのLC/MS/ MS データを取得した（Fig. 1, (1)，(2)）取得したデータを 用い, “enzyme”として“Trypsin”を選択し，SwissProt データベースに対してMASCOT検索を行い, 試料中に含 まれるタンパク質の同定を行った。“Taxonomy”は“all entries”を選択した。その結果TRYP_PIGが 1,113のトッ プスコアで同定され，計65個のクエリーがTRYP_PIG由 来の 5 種類の断片ペプチドにマッチした（Table 1). TRYP_PIG以外に 2 種類以上のペプチドが有意にマッチし たタンパク質は, 同一の組み合わせの 4 個のクエリーが マッチしたKeratin, type II cytoskeletal 1（K2C1_HUMAN, K2C1_CANLF, K2C1_PANTR）およびKeratin, type II cytoskeletal 1b（K2C1B_MOUSE, K2C1B_RAT）であり，スコ アは146であった。この結果から，取得されたLC/MS/MS 


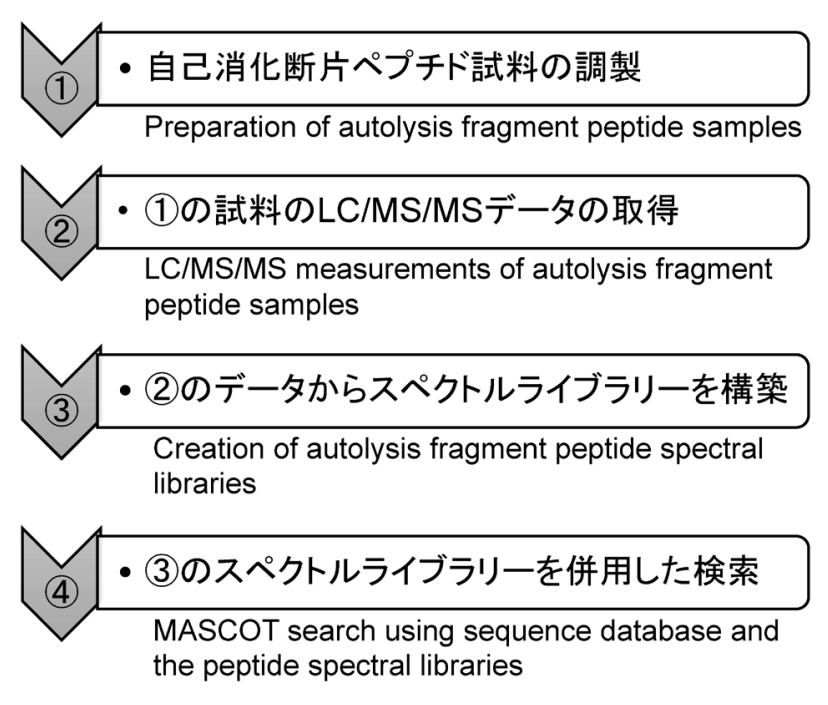

Fig. 1. A flowchart of the proposed database search strategy using spectral libraries to identify autolysis peptide fragments from chemically modified trypsin.
のデータは，ほぼ化学修飾トリプシンの自己消化断片ペプ チドに由来したスペクトルデータで構成されているとみな した.

次に化学修飾トリプシンに存在する修飾基を明らかにす るために，同じLC/MS/MSデータを用いて“error tolerant search”をオンにしたMASCOT MS/MS ion searchを行っ た. その結果 Table 2 に示した 8 種類の修飾が存在すること が示唆された。

\section{2 化学修飾トリプシン由来スペクトルライブラリー の作成}

次に，化学修飾トリプシン由来スペクトルライブラリー を作成するにあたり（Fig. 1, (3)），存在が示唆された修飾 基を有する断片ぺプチドや, Lys-X, Arg-X以外のトリプシ ンの非特異的な加水分解によって生成された断片ペプチド など，この試料中に含まれている，通常の検索条件では同 定できない化学修飾トリプシン由来の自己消化断片ペプチ ドのアミノ酸配列と修飾基の情報を得るために，“Variable

Table 1. Data for Peptide Sequences Matched to TRYP_PIG in a Result of a MASCOT Search of an Autolyzed Digest of Chemically Modified Trypsin, Using Normal Search Parameters

\begin{tabular}{|c|c|c|c|c|c|c|c|c|}
\hline $\mathrm{N}$ & $\mathrm{C}$ & -1 & Amino acid sequence & $\begin{array}{c}\text { Observed } \\
m / z\end{array}$ & $\begin{array}{l}\text { Charge } \\
\text { number }\end{array}$ & $\begin{array}{c}\text { Observed } \\
\text { monoisotopic } \\
\text { mass/Da }\end{array}$ & $\begin{array}{c}\text { Calculated } \\
\text { monoisotopic } \\
\text { mass/Da }\end{array}$ & $\begin{array}{l}\text { Error } \\
(\mathrm{ppm})\end{array}$ \\
\hline 58 & 77 & $\mathrm{R}$ & LGEHNIDVLEGNEQFINAAK & 1106.0557 & 2 & 2210.0968 & 2210.0967 & 0.0 \\
\hline 58 & 77 & $\mathrm{R}$ & LGEHNIDVLEGNEQFINAAK & 737.7055 & 3 & 2210.0947 & 2210.0967 & -0.9 \\
\hline 78 & 97 & $\mathrm{~K}$ & IITHPNFNGNTLDNDIMLIK & 761.7311 & 3 & 2282.1714 & 2282.1729 & -0.7 \\
\hline 78 & 97 & $\mathrm{~K}$ & IITHPNFNGNTLDNDIMLIK & 571.5508 & 4 & 2282.1740 & 2282.1729 & 0.5 \\
\hline 78 & 107 & $\mathrm{~K}$ & IITHPNFNGNTLDNDIMLIKLSSPATLNSR & 828.4368 & 4 & 3309.7182 & $3309.7216^{*}$ & -1.0 \\
\hline 98 & 107 & $\mathrm{~K}$ & LSSPATLNSR & 523.2852 & 2 & 1044.5558 & 1044.5564 & -0.6 \\
\hline 108 & 115 & $\mathrm{R}$ & VATVSLPR & 421.7586 & 2 & 841.5026 & 841.5022 & 0.5 \\
\hline
\end{tabular}

$\mathrm{N}$ : Residue number of the $\mathrm{N}$-terminal amino acid residue of the matched sequence.

$\mathrm{C}$ : Residue number of the $\mathrm{C}$-terminal amino acid residue of the matched sequence.

-1 : Amino acid residue one residue before the $\mathrm{N}$-terminal of the matched sequence.

*: Based on composition containing one atom of ${ }^{13} \mathrm{C}$.

Used Search Parameters

$\begin{array}{ll}\text { Type of search: } & \text { MS/MS ion search } \\ \text { Database: } & \text { SwissProt_2020_05 } \\ \text { Taxonomy: } & \text { All entries } \\ \text { Enzyme: } & \text { Trypsin } \\ \text { Max missed cleavages: } & 2 \\ \text { Fixed modifications: } & \text { None } \\ \text { Variable modifications: } & \text { None } \\ \text { Peptide mass tolerance: } & 4 \text { ppm }(\# 13 \mathrm{C}=1) \\ \text { Fragment mass tolerance: } & 0.8 \mathrm{Da} \\ \text { Instrument type: } & \text { ESI-TRAP }\end{array}$

Table 2. Modifications Detected in an "Error Tolerant Search" of MASCOT MS/MS Ions Search Based on the LC/MS/MS Data of Chemically Modified Trypsin Autolysis Peptides

\begin{tabular}{llc}
\hline \multicolumn{1}{c}{$\begin{array}{c}\text { Notation in } \\
\text { MASCOT }\end{array}$} & \multicolumn{1}{c}{ Modification } & Monoisotopic mass difference/Da \\
\hline Methyl (K) & Monomethylation of $\varepsilon$-amino group of Lys & +14.0157 \\
Dimethyl (K) & Dimethylation of $\varepsilon$-amino group of Lys & +28.0313 \\
Methyl (N-term) & Monomethylation of $\alpha$-amino group of N-terminal & +14.0157 \\
Dimethyl (N-term) & Dimethylation of $\alpha$-amino group of N-terminal & +28.0313 \\
Deamidated (N) & Deamidation of Asn (Conversion of Asn to Asp) & +0.9840 \\
Deamidated (Q) & Deamidation of Gln (Conversion of Gln to Glu) & +0.9840 \\
Oxidation (M) & Oxidation of Met & +15.9949 \\
Kynurenin (W) & Conversion of Trp to Kynurenine residue & +3.9949 \\
\hline
\end{tabular}


Table 3. Comparison of the Search Parameters Used among Six Search Strategies for the Identification of Autolysis Fragment Peptides of Chemically Modified Trypsin in an In-Gel Digest, in This Study

\begin{tabular}{|c|c|c|c|c|c|c|}
\hline & \multicolumn{6}{|c|}{ Search strategy } \\
\hline & A & B & $\mathrm{C}$ & $\mathrm{D}$ & $\mathrm{E}$ & $\mathrm{F}$ \\
\hline Enzyme & Trypsin & None & Trypsin & Trypsin & Trypsin & Trypsin \\
\hline Variable modification & Carbamidomethyl (C) & $\begin{array}{l}\text { Carbamidomethyl (C) } \\
\text { Methyl (K, N-term) } \\
\text { Dimethyl (K, N-term) } \\
\text { Deamidated (N, Q) } \\
\text { Kynurenin (W) }\end{array}$ & Carbamidomethyl（C) & Carbamidomethyl (C) & Carbamidomethyl（C) & Carbamidomethyl (C) \\
\hline Database & $\begin{array}{c}\text { SwissProt } \\
\text { cRAP }\end{array}$ & cRAP & $\begin{array}{c}\text { SwissProt } \\
\text { cRAP } \\
\text { Promega_Trypsin_SG1 }\end{array}$ & $\begin{array}{c}\text { SwissProt } \\
\text { cRAP } \\
\text { Promega_Trypsin_SG2 }\end{array}$ & $\begin{array}{c}\text { SwissProt } \\
\text { cRAP } \\
\text { Promega_Trypsin_SG1 } \\
\text { Promega_Trypsin_SG2 }\end{array}$ & $\begin{array}{c}\text { SwissProt } \\
\text { cRAP } \\
\text { PRIDE_Contaminants }\end{array}$ \\
\hline Taxonomy & Homo spiens (Human) & All entries & Homo spiens (Human) & Homo spiens (Human) & Homo spiens (Human) & Homo spiens (Human) \\
\hline
\end{tabular}

modification”として Table 2にリストアップされた修飾を 選択し, “enzyme”を“none”に設定し MASCOT MS/MS ion searchを行った.

TRIP_PIGにマッチしたスペクトルデータの中からスペ クトルライブラリーに収録するデータを選択するにあた り，スペクトルライブラリーを用いた検索での擬陽性を防 ぐために，本検索結果において誤同定のおそれがあるデー 夕を収録させない必要がある。そのため, decoyデータ ベースを対象とした検索においてスペクトルデータが偶然 にマッチするペプチドの数と期待值（ $p$ ）との相関を調べ た. Significant thresholdをデフォルト值の $p<0.05$ に設定 した場合, decoyデータベースを対象とした検索において スペクトルデータが偶然にマッチしたペプチド数は 17 , $p<0.01$ に設定した場合は 1 であったが， $p<0.005$ に設定 した場合は 0 となった。したがって，スペクトルライブラ リーを作成する条件として, 今回のデータの場合はSignificant threshold を $p<0.005$ に設定した場合, 擬陽性を生じ させる確率を大幅に軽減できると判断した。

Significant threshold $p<0.005$ に設定した際, 計 396 の クエリーがTRYP_PIGのアミノ酸配列にマッチした．Table 1 の結果との単純な比較はできないが, Significant thresholdの条件を $p<0.005$ と 10 倍厳しくしたにもかかわ らず，約6倍の数のクエリーがTRYP_PIGにマッチした.

スペクトルライブラリーを作成する際は，アミノ酸配列 と修飾基の種類と位置の情報が同じスペクトルデータで あっても, プリカーサーイオンの価数が異なる場合は, 異 なるエントリーとして収録される.一方, アミノ酸配列と 修飾基の種類と位置, イオンの価数が同じ場合は, 最もス コアの高いスペクトルデータ 1 種類がエントリーされる. 本研究で取得した化学修飾トリプシン自己消化断片ペプチ ドの LC/MS/MSデータからは, アミノ酸配列, 修飾基の 種類と位置, イオンの価数が異なるTRYP_PIGにマッチし た 166 種類のスペクトルデータが抽出され, このスペクト ルライブラリーを化学修飾トリプシンスペクトルライブラ リー “Trypsin_Promega_SG1”とした注4). 収録されたス ペクトルデータのアミノ酸配列や修飾等の情報を Support- ing Information 1 に示した注5).

\section{3 化学修飾トリプシンスペクトルライブラリーを用 いたゲル内消化物中の想定外自己消化断片ペプチドの 同定}

化学修飾トリプシンスペクトルライブラリー “Trypsin_ Promega_SG1”を使用した検索と使用しない通常の検索に おける，ゲル内消化物に含まれる化学修飾トリプシン自己 消化断片ペプチドの同定結果の比較を行った.

ヒト由来培養細胞から調製した試料のドデシル硫酸ナト リウムポリアクリルアミドゲル電気泳動によって得られた あるタンパク質バンドの化学修飾トリプシンゲル内消化物 を分析したLC/MS/MSデータを利用した。

最初に，プロテオミクスで利用される一般的な検索条件 （本稿ではSearch Strategy A とする）を用いた検索を行い, 同定されるぺプチドを確認した。ゲル内消化時にヨードア セドアミドを用いたゲル内還元アルキル化を行っているこ とから, “Variable modification”として “Carbamidomethyl （C）”を選択した（Table 3, Search Strategy A). その結果, Table 4 の Search Strategy Aの列で○によって示した 10 種 の断片ペプチドが同定された. Arg-Xが加水分解されるこ とによって生じるVATVSLPR（108-115）の断片ペプチド が検出されるのは当然であるが, Lys残基にメチル化処理 が施されている化学修飾トリプシンを用いたにもかかわら ず未修飾の Lys残基を含む断片ぺプチドが数多く検出され ている. “Variable modification”として “Methyl (K)”と “Dimethyl（K）”を選択していないため，存在しているは ずのモノメチル化Lys残基やジメチル化Lys 残基を含んだ 断片ペプチドは同定されていない.

Supporting Information 1で示された結果は, 化学修飾卜 リプシンの自己消化断片ペプチドには一般的に利用される 検索条件では同定することができない多種多様な断片ぺプ チドが存在していることを示している．ゲル内消化物由来

注4）Spectral libraries Trypsin_Promega_SG1 and Trypsin_Promega_SG2: http://www.matrixscience.co.jp/SLdata/SLmsp.zip

注 5) Supporting Information 1: http://www.matrixscience.co.jp/ SLdata/Yoshino_Usami_Takeuchi_Supporting_Information_1.pdf 
Table 4. Comparison of Identified Peptides Matching TRYP_PIG in the MASCOT Search, Using Six Different Search Strategies, with the Same LC/MS/MS Data Set Obtained from an In-Gel Digest

\begin{tabular}{|c|c|c|c|c|c|c|c|c|c|c|c|}
\hline \multirow{2}{*}{$\mathrm{N}$} & \multirow{2}{*}{$\mathrm{C}$} & \multirow{2}{*}{-1} & \multirow{2}{*}{ Amino acid sequence } & \multirow{2}{*}{ Modification } & \multirow{2}{*}{$\begin{array}{l}\text { Charge } \\
\text { number }\end{array}$} & \multicolumn{6}{|c|}{ Search strategy } \\
\hline & & & & & & A & $\mathrm{B}$ & $\mathrm{C}$ & $\mathrm{D}$ & $\mathrm{E}$ & $\mathrm{F}$ \\
\hline 9 & 18 & $\mathrm{~K}$ & IVGGYTCAAN & Carbamidomethyl $\left(C^{15}\right)$ & 2 & $x$ & 0 & $\triangle$ & $\triangle$ & $\triangle$ & \\
\hline 9 & 22 & K & IVGGYTCAANSIPY & Carbamidomethyl $\left(\mathrm{C}^{15}\right)$ & 2 & $x$ & 0 & $\triangle$ & $\triangle$ & $\triangle$ & \\
\hline 9 & 27 & $\mathrm{~K}$ & IVGGYTCAANSIPYQVSLN & Carbamidomethyl $\left(\mathrm{C}^{15}\right)$ & 2 & $x$ & $\bigcirc$ & $\triangle$ & $\triangle$ & $\triangle$ & \\
\hline 9 & 28 & $\mathrm{~K}$ & IVGGYTCAANSIPYQVSLNS & Carbamidomethyl $\left(\mathrm{C}^{15}\right)$ & 2 & $x$ & $\bigcirc$ & $\triangle$ & $\triangle$ & $\triangle$ & \\
\hline 9 & 29 & K & IVGGYTCAANSIPYQVSLNSG & Carbamidomethyl $\left(\mathrm{C}^{15}\right)$ & 2 & $\times$ & $\bigcirc$ & $\triangle$ & $\triangle$ & $\triangle$ & \\
\hline 19 & 27 & $\mathrm{~N}$ & SIPYQVSLN & & 2 & $x$ & $\bigcirc$ & $\bigcirc$ & $\triangle$ & $\bigcirc$ & \\
\hline 28 & 39 & $\mathrm{~N}$ & SGSHFCGGSLIN & Carbamidomethyl $\left(C^{33}\right)$ & 2 & $x$ & $\bigcirc$ & $\triangle$ & $\triangle$ & $\triangle$ & \\
\hline 40 & 48 & $\mathrm{~N}$ & SQWVVSAAH & & 2 & $x$ & $\bigcirc$ & $\bigcirc$ & $\bigcirc$ & $\bigcirc$ & \\
\hline 58 & 71 & $\mathrm{R}$ & LGEHNIDVLEGNEQ & & 2 & $x$ & $\bigcirc$ & $\triangle$ & $\bigcirc$ & $\bigcirc$ & \\
\hline 58 & 74 & $\mathrm{R}$ & LGEHNIDVLEGNEQFIN & & 2 & $\times$ & $\bigcirc$ & $\bigcirc$ & $\bigcirc$ & $\bigcirc$ & \\
\hline 58 & 75 & $\mathrm{R}$ & LGEHNIDVLEGNEQFINA & & 2 & $x$ & $\bigcirc$ & $\bigcirc$ & $\bigcirc$ & $\bigcirc$ & \\
\hline 58 & 77 & $\mathrm{R}$ & LGEHNIDVLEGNEQFINAAK & & 2 & $\bigcirc$ & $\bigcirc$ & $\bigcirc$ & $\bigcirc$ & $\bigcirc$ & $\bigcirc$ \\
\hline 58 & 77 & $\mathrm{R}$ & LGEHNIDVLEGNEQFINAAK & & 3 & $\bigcirc$ & $\bigcirc$ & $\bigcirc$ & $\bigcirc$ & $\bigcirc$ & O \\
\hline 58 & 77 & $\mathrm{R}$ & LGEHNIDVLEGNEQFINAAK & Monomethyl $\left(\mathrm{K}^{77}\right)$ & 2 & $x$ & $\bigcirc$ & $\bigcirc$ & $\bigcirc$ & $\bigcirc$ & \\
\hline 58 & 77 & $\mathrm{R}$ & LGEHNIDVLEGNEQFINAAK & Monomethyl $\left(\mathrm{K}^{77}\right)$ & 3 & $\times$ & $\bigcirc$ & $\bigcirc$ & $\bigcirc$ & $\bigcirc$ & \\
\hline 58 & 77 & $\mathrm{R}$ & LGEHNIDVLEGNEQFINAAK & Dimethyl $\left(K^{77}\right)$ & 3 & $x$ & $\bigcirc$ & $\bigcirc$ & $\bigcirc$ & $\bigcirc$ & \\
\hline 58 & 77 & $\mathrm{R}$ & LGEHNIDVLEGNEQFINAAK & Deamidated $\left(\mathrm{N}^{62}\right)$ & 3 & $x$ & 0 & $\times$ & $\triangle$ & $\times$ & \\
\hline 58 & 77 & $\mathrm{R}$ & LGEHNIDVLEGNEQFINAAK & Deamidated $\left(\mathrm{N}^{74}\right)$ & 3 & $x$ & $\bigcirc$ & $\times$ & $\overline{0}$ & $\bigcirc$ & \\
\hline 58 & 77 & $\mathrm{R}$ & LGEHNIDVLEGNEQFINAAK & $\begin{array}{l}\text { Deamidated }\left(\mathrm{N}^{74}\right) \text {, } \\
\text { Monomethyl }\left(\mathrm{K}^{77}\right)\end{array}$ & 3 & $\times$ & $\bigcirc$ & $\triangle$ & $\bigcirc$ & $\bigcirc$ & \\
\hline 58 & 77 & $\mathrm{R}$ & LGEHNIDVLEGNEQFINAAK & Deamidated $\left(\mathrm{Q}^{71}\right)$ & 3 & $x$ & $\bigcirc$ & $\triangle$ & $\triangle$ & $\triangle$ & \\
\hline 58 & 83 & $\mathrm{R}$ & LGEHNIDVLEGNEQFINAAKIITHPN & Dimethyl $\left(K^{77}\right)$ & 4 & $\times$ & $\bigcirc$ & $\bigcirc$ & $\bigcirc$ & $\bigcirc$ & \\
\hline 58 & 107 & $\mathrm{R}$ & $\begin{array}{l}\text { LGEHNIDVLEGNEQFINAAKIITHPNF- } \\
\text { NGNTLDNDIMLIKLSSPATLNSR }\end{array}$ & Dimethyl $\left(\mathrm{K}^{77}, \mathrm{~K}^{97}\right)$ & 5 & $x$ & $\bigcirc$ & $\bigcirc$ & $\bigcirc$ & $\bigcirc$ & \\
\hline 58 & 107 & $\mathrm{R}$ & $\begin{array}{l}\text { LGEHNIDVLEGNEQFINAAKIITHPNF- } \\
\text { NGNTLDNDIMLIKLSSPATLNSR }\end{array}$ & $\begin{array}{l}\text { Dimethyl }\left(K^{77}, K^{97}\right) \\
\text { Deamidated }\left(N^{85}\right)\end{array}$ & 5 & $x$ & $\times$ & $\bigcirc$ & $\triangle$ & $\bigcirc$ & \\
\hline 58 & 107 & $\mathrm{R}$ & $\begin{array}{l}\text { LGEHNIDVLEGNEQFINAAKIITHPNF- } \\
\text { NGNTLDNDIMLIKLSSPATLNSR }\end{array}$ & $\begin{array}{l}\text { Dimethyl }\left(\mathrm{K}^{77}, \mathrm{~K}^{97}\right) \text {, } \\
\text { Deamidated }\left(\mathrm{N}^{91}\right)\end{array}$ & 5 & $\times$ & $x$ & $\triangle$ & $\bigcirc$ & $\times$ & \\
\hline 58 & 107 & $\mathrm{R}$ & $\begin{array}{l}\text { LGEHNIDVLEGNEQFINAAKIITHPNF- } \\
\text { NGNTLDNDIMLIKLSSPATLNSR }\end{array}$ & $\begin{array}{l}\text { Dimethyl }\left(\mathrm{K}^{77}, \mathrm{~K}^{97}\right) \\
\text { Deamidated }\left(\mathrm{N}^{105}\right)\end{array}$ & 5 & $x$ & $x$ & $\triangle$ & $\bigcirc$ & $\times$ & \\
\hline 62 & 74 & $\mathrm{H}$ & NIDVLEGNEQFIN & & 2 & $\times$ & $\bigcirc$ & $\bigcirc$ & $\bigcirc$ & $\bigcirc$ & \\
\hline 75 & 87 & $\mathrm{~N}$ & AAKIITHPNFNGN & $\begin{array}{l}\text { Monomethyl (N-term), } \\
\text { Monomethyl }\left(\mathrm{K}^{77}\right)\end{array}$ & 2 & $x$ & $\bigcirc$ & $\triangle$ & $\triangle$ & $\triangle$ & \\
\hline 75 & 87 & $\mathrm{~N}$ & AAKIITHPNFNGN & Dimethyl $\left(K^{77}\right)$ & 2 & $x$ & $\bigcirc$ & $\bigcirc$ & $\bigcirc$ & $\bigcirc$ & \\
\hline 78 & 87 & $\mathrm{~K}$ & IITHPNFNGN & & 2 & $x$ & $\bigcirc$ & $\bigcirc$ & $\bigcirc$ & $\bigcirc$ & $\bigcirc$ \\
\hline 78 & 97 & K & IITHPNFNGNTLDNDIMLIK & & 3 & $\bigcirc$ & $\bigcirc$ & $\bigcirc$ & $\bigcirc$ & $\bigcirc$ & $\bigcirc$ \\
\hline 78 & 97 & K & IITHPNFNGNTLDNDIMLIK & Oxidation $\left(\mathrm{M}^{94}\right)$ & 3 & $x$ & $\bigcirc$ & $\bigcirc$ & $\bigcirc$ & $\bigcirc$ & $\bigcirc$ \\
\hline 78 & 97 & $\mathrm{~K}$ & IITHPNFNGNTLDNDIMLIK & Monomethyl $\left(\mathrm{K}^{97}\right)$ & 3 & $\times$ & $\bigcirc$ & $\bigcirc$ & $\bigcirc$ & $\bigcirc$ & \\
\hline 78 & 107 & $\mathrm{~K}$ & IITHPNFNGNTLDNDIMLIKLSSPATLNSR & Monomethyl $\left(\mathrm{K}^{97}\right)$ & 4 & $\times$ & $\bigcirc$ & $\triangle$ & $\bigcirc$ & $\bigcirc$ & \\
\hline 78 & 107 & $\mathrm{~K}$ & IITHPNFNGNTLDNDIMLIKLSSPATLNSR & Dimethyl $\left(K^{97}\right)$ & 4 & $\times$ & $\bigcirc$ & $\bigcirc$ & $\bigcirc$ & $\bigcirc$ & \\
\hline 84 & 107 & $\mathrm{~N}$ & FNGNTLDNDIMLIKLSSPATLNSR & Dimethyl $\left(K^{97}\right)$ & 3 & $\times$ & $\bigcirc$ & $\bigcirc$ & $\bigcirc$ & $\bigcirc$ & \\
\hline 84 & 107 & $\mathrm{~N}$ & FNGNTLDNDIMLIKLSSPATLNSR & $\begin{array}{l}\text { Dimethyl }\left(\mathrm{K}^{97}\right) \\
\text { Oxidation }\left(\mathrm{M}^{94}\right)\end{array}$ & 3 & $\times$ & $x$ & $\bigcirc$ & $x$ & $\bigcirc$ & \\
\hline 88 & 97 & $\mathrm{~N}$ & TLDNDIMLIK & Monomethyl $\left(\mathrm{K}^{97}\right)$ & 2 & $x$ & $\bigcirc$ & 0 & 0 & 0 & \\
\hline 88 & 98 & $\mathrm{~N}$ & TLDNDIMLIKL & Dimethyl $\left(\mathrm{K}^{97}\right)$ & 2 & $\times$ & $\bigcirc$ & $\triangle$ & $\bigcirc$ & $\bigcirc$ & \\
\hline 88 & 98 & $\mathrm{~N}$ & TLDNDIMLIKL & $\begin{array}{l}\text { Dimethyl }\left(\mathrm{K}^{97}\right) \\
\text { Oxidation }\left(\mathrm{M}^{94}\right)\end{array}$ & 2 & $x$ & $\bigcirc$ & $\triangle$ & $\bigcirc$ & $\bigcirc$ & \\
\hline 88 & 102 & $\mathrm{~N}$ & TLDNDIMLIKLSSPA & Dimethyl $\left(\mathrm{K}^{97}\right)$ & 2 & $x$ & $\bigcirc$ & $\triangle$ & $\bigcirc$ & $\times$ & \\
\hline 88 & 105 & $\mathrm{~N}$ & TLDNDIMLIKLSSPATLN & Dimethyl $\left(K^{97}\right)$ & 2 & $x$ & $\bigcirc$ & $\triangle$ & $\bigcirc$ & $\bigcirc$ & \\
\hline 88 & 107 & $\mathrm{~N}$ & TLDNDIMLIKLSSPATLNSR & Dimethyl $\left(K^{97}\right)$ & 3 & $\times$ & $\bigcirc$ & $\bigcirc$ & 0 & $\bigcirc$ & \\
\hline 95 & 105 & $\mathrm{M}$ & LIKLSSPATLN & Dimethyl $\left(K^{97}\right)$ & 2 & $x$ & $\bigcirc$ & $\bigcirc$ & $\bigcirc$ & $\bigcirc$ & \\
\hline 96 & 105 & $\mathrm{~L}$ & IKLSSPATLN & Dimethyl $\left(K^{97}\right)$ & 2 & $x$ & $\bigcirc$ & $\triangle$ & $\bigcirc$ & $\bigcirc$ & \\
\hline 96 & 107 & $\mathrm{~L}$ & IKLSSPATLNSR & Dimethyl $\left(K^{97}\right)$ & 2 & $x$ & $\bigcirc$ & 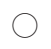 & $\bigcirc$ & $\bigcirc$ & \\
\hline 98 & 107 & $\mathrm{~K}$ & LSSPATLNSR & & 2 & 0 & 0 & 0 & 0 & 0 & 0 \\
\hline 99 & 107 & $\mathrm{~L}$ & SSPATLNSR & & 2 & $x$ & $\bigcirc$ & $x$ & $x$ & $x$ & \\
\hline 100 & 107 & S & SPATLNSR & & 2 & $\times$ & $\bigcirc$ & $\bigcirc$ & $\triangle$ & $\bigcirc$ & 0 \\
\hline 101 & 107 & S & PATLNSR & & 2 & $\times$ & $x$ & 0 & $\triangle$ & 0 & 0 \\
\hline 108 & 115 & $\mathrm{R}$ & VATVSLPR & & 2 & $\bigcirc$ & $\bigcirc$ & $\bigcirc$ & $\bigcirc$ & $\bigcirc$ & $\bigcirc$ \\
\hline 108 & 115 & $\mathrm{R}$ & VATVSLPR & Monomethyl（N-term） & 2 & $\times$ & $\bigcirc$ & $\bigcirc$ & $\triangle$ & $\bigcirc$ & \\
\hline 108 & 115 & $\mathrm{R}$ & VATVSLPR & Dimethyl（N-term） & 2 & $x$ & $\bigcirc$ & $x$ & $\bigcirc$ & $\bigcirc$ & \\
\hline 116 & 131 & $\mathrm{R}$ & SCAAAGTECLISGWGN & Carbamidomethyl $\left(\mathrm{C}^{117}, \mathrm{C}^{124}\right)$ & 2 & $\times$ & $\bigcirc$ & $\triangle$ & $\triangle$ & $\triangle$ & \\
\hline
\end{tabular}


吉野健一・宇佐見 至・竹内敦子

Table 4. Continued

\begin{tabular}{|c|c|c|c|c|c|c|c|c|c|c|c|}
\hline \multirow{2}{*}{$\mathrm{N}$} & \multirow{2}{*}{$\mathrm{C}$} & \multirow{2}{*}{-1} & \multirow{2}{*}{ Amino acid sequence } & \multirow{2}{*}{ Modification } & \multirow{2}{*}{$\begin{array}{l}\text { Charge } \\
\text { number }\end{array}$} & \multicolumn{6}{|c|}{ Search strategy } \\
\hline & & & & & & A & $\mathrm{B}$ & C & $\mathrm{D}$ & E & $\mathrm{F}$ \\
\hline 116 & 133 & $\mathrm{R}$ & SCAAAGTECLISGWGNTK & $\begin{array}{l}\text { Carbamidomethyl }\left(\mathrm{C}^{117}, \mathrm{C}^{124}\right) \text {, } \\
\text { Dimethyl }\left(\mathrm{K}^{133}\right)\end{array}$ & 2 & $x$ & O & $\triangle$ & $\triangle$ & $\triangle$ & \\
\hline 126 & 133 & $\mathrm{~L}$ & ISGWGNTK & Dimethyl $\left(\mathrm{K}^{133}\right)$ & 2 & $\times$ & $\times$ & $\bigcirc$ & $\times$ & $\bigcirc$ & \\
\hline 134 & 147 & $\mathrm{~K}$ & SSGSSYPSLLQCLK & Carbamidomethyl $\left(\mathrm{C}^{145}\right)$ & 2 & $\widehat{0}$ & $\widehat{0}$ & 0 & $\widehat{0}$ & 0 & 0 \\
\hline 148 & 157 & K & APVLSDSSCK & Carbamidomethyl $\left(\mathrm{C}^{156}\right)$ & 2 & 0 & 0 & 0 & 0 & $\bigcirc$ & 0 \\
\hline 148 & 167 & $\mathrm{~L}$ & APVLSDSSCKSSYPGQITGN & $\begin{array}{l}\text { Carbamidomethyl }\left(\mathrm{C}^{156}\right) \text {, } \\
\text { Dimethyl }\left(\mathrm{K}^{157}\right)\end{array}$ & 2 & $x$ & 0 & $\triangle$ & $\triangle$ & $\triangle$ & \\
\hline 158 & 167 & K & SSYPGQITGN & & 2 & $\times$ & $\bigcirc$ & $\bigcirc$ & $\bigcirc$ & $\bigcirc$ & O \\
\hline 209 & 216 & $\mathrm{~K}$ & NKPGVYTK & & 2 & 0 & $x$ & $\triangle$ & 0 & 0 & \\
\hline 209 & 216 & K & NKPGVYTK & & 3 & 0 & $x$ & $\triangle$ & 0 & 0 & \\
\hline 209 & 216 & $\mathrm{~K}$ & NKPGVYTK & Dimethyl $\left(K^{210}\right)$ & 2 & $x$ & $\bigcirc$ & 0 & $\triangle$ & 0 & \\
\hline 215 & 231 & $\mathrm{Y}$ & TKVCNYVNWIQQTIAAN & $\begin{array}{l}\left.\text { Monomethyl (N-term, } \mathrm{K}^{216}\right) \text {, } \\
\text { Carbamidomethyl }\left(\mathrm{C}^{218}\right)\end{array}$ & 2 & $x$ & 0 & $\triangle$ & $\triangle$ & $\triangle$ & \\
\hline 217 & 231 & $\mathrm{~V}$ & VCNYVNWIQQTIAAN & Carbamidomethyl $\left(\mathrm{C}^{218}\right)$ & 2 & $\bigcirc$ & $\bigcirc$ & $\bigcirc$ & $\bigcirc$ & $\bigcirc$ & $\bigcirc$ \\
\hline 215 & 231 & $\mathrm{Y}$ & TKVCNYVNWIQQTIAAN & $\begin{array}{l}\text { Dimethyl (N-term), } \\
\text { Carbamidomethyl }\left(C^{218}\right)\end{array}$ & 2 & $\times$ & 0 & $\triangle$ & $\triangle$ & $\triangle$ & \\
\hline 220 & 227 & $\mathrm{~N}$ & YVNWIQQT & & 2 & $x$ & $\bigcirc$ & $\bigcirc$ & 0 & $\bigcirc$ & \\
\hline 220 & 231 & $\mathrm{~N}$ & YVNWIQQTIAAN & & 2 & $x$ & 0 & 0 & 0 & 0 & $\bigcirc$ \\
\hline 220 & 231 & $\mathrm{~N}$ & YVNWIQQTIAAN & Deamidated $\left(\mathrm{N}^{222}\right)$ & 2 & $x$ & $x$ & $\triangle$ & 0 & 0 & \\
\hline 220 & 231 & $\mathrm{~N}$ & YVNWIQQTIAAN & Deamidated $\left(\mathrm{Q}^{225}\right)$ & 2 & $x$ & 0 & $\triangle$ & $\triangle$ & $\triangle$ & \\
\hline 220 & 231 & $\mathrm{~N}$ & YVNWIQQTIAAN & Deamidated $\left(\mathrm{Q}^{226}\right)$ & 2 & $\times$ & 0 & 0 & 0 & 0 & \\
\hline 223 & 231 & $\mathrm{~N}$ & WIQQTIAAN & & 2 & $x$ & $x$ & 0 & 0 & 0 & \\
\hline
\end{tabular}

$\mathrm{N}$ : Residue number of the $\mathrm{N}$-terminal amino acid residue of the matched sequence.

$\mathrm{C}$ : Residue number of the $\mathrm{C}$-terminal amino acid residue of the matched sequence.

-1 : Amino acid residue one residue before the $\mathrm{N}$-terminal of the matched sequence.

$\bigcirc$ : Identified with significant expect value.

$x$ : Not identified with significant expect value.

$\triangle$ : Spectral data are not stored in the spectral library.

の LC/MS/MS スペクトルデータ中にも, Table 2でリスト アップされている修飾基を有する断片ペプチドや, Lys-X やArg-X以外の非特異的な加水分解によって生成された断 片ペプチドなど, 多種多様な想定外の化学修飾トリプシン 由来断片ペプチドに由来するスペクトルデータが数多く含 まれている可能性が高い.このゲル内消化物由来の LC/ MS/MSデータに含まれている化学修飾トリプシン自己消 化断片ペプチド由来のデータの情報を得るために，“Variable modification”として Table 2にリストアップされた 8 種類の修飾と“Carbamidomethyl (C)” を, “enzyme” として“none”を選択して検索を行った（Table 3, Search Strategy B). アミノ酸配列や修飾基, 価数の異なる 61 種類 の断片ペプチドが同定された（Table 4, Search Strategy Bの 列で○と表示された断片ペプチド). TRYP_PIGにマッチ したクエリー数は157であった．通常の検索条件（Table 3, Search Strategy A）で得られた同定結果においてTRYP_ PIGにマッチしたクエリー数は68であったことから，化 学修飾トリプシン自己消化断片ペプチド由来の890クエ リーが，特定のタンパク質の配列にマッチしなかったか, 可能性としては高くはないが別のペプチドとして同定され ていたおそれもある。

通常の検索で用いられる Search Strategy A の検索条件に 加えて, 本研究で作成した化学修飾トリプシンスペクトル ライブラリー“Trypsin_Promega_SG1”を検索対象データ ベースに加えた検索（Table 3, Search Strategy C）を行った
ところ（Fig. 1, (4)），アミノ酸配列や修飾基，価数の異な る40種類の断片ペプチドが同定された（Table 4, Search Strategy Cの列で○と表記された断片ペプチド). Search Strategy Aでは価数の違いを含めて 10 種類の断片ペプチド のみが同定されたが，化学修飾トリプシンスペクトルライ ブラリー“Trypsin_Promega_SG1”を検索対象データベー スに加えるだけで，さらに30種類の断片ぺプチドを同定 することが可能となった。

負荷がかかる Search Strategy Bの検索で同定された 61 種 類の断片ペプチドのうち，S-カルバミドメチル化 Cys 残基 を含む断片ぺプチドは 14 種類であった。“Trypsin_Promega_SG1”は，S-カルバミドメチル化処理を施していない 化学修飾トリプシンを試料とした分析によって得られた データから作成されていることから，S-カルバミドメチル 化Cys残基を含んだ断片ペプチドのスペクトルデータはス ペクトルライブラリーに収録されていない。したがって “Trypsin_Promega_SG1”を使用してもS-カルバミドメチ ル化Cys残基を含む14種類を同定することはできない. それゆえ, Table 4においては, スペクトルライブラリー にスペクトルデータが収録されていないために同定できな かったことを意味する $\triangle$ と表記した。 ただし，トリプシン の特異的な加水分解によって生じ，ジメチル化されていな い3種の断片ペプチドはスペクトルライブラリーを利用せ ずとも同定できるため○と表示されている. 
3.4 スペクトルデータがライブラリーに収録されてい るにもかかわらず同定できないクエリーの存在

Search Strategy Bの検索で同定された 61 種類の断片ペプ チドのうち，S-カルバミドメチル化Cys残基を含んだ断片 ペプチド以外はSearch Strategy Cの検索ですべて同定され ることを期待したが，15種類の断片ペプチドは同定され なかった。 その一方で, Search Strategy Bでは同定されて いなかった6種類の断片ペプチドが同定されていた。

同定されなかった 15 種の断片ペプチドのうち 11 種類は “Trypsin_Promega_SG1”に収録されていなかった．残り の 4 種類はスペクトルデータが収録されていたにもかかわ らず同定されなかった。

Search Strategy Cによる検索では, トリプシンの特異的 な加水分解によって生じた断片ペプチドに由来するデータ は, 通常の配列データを利用する検索も並行して行われ, スペクトルライブラリーのデータとの合致度よりも信頼性 が高い場合には配列データから同定された結果として示さ れる. Fig. 2 にSearch Strategy Cによる同定結果の一部を 示した.19のクエリーがLGEHNIDVLEGNEQFINAAK （58-77）とマッチしていると判断された. Sourceの列に SL と記されているクエリーはスペクトルライブラリーに よって同定されたスペクトルデータ，AAと記されたクエ リーはスペクトルライブラリーによって同定されず，配列 データを利用した通常の検索によって同定されたスペクト ルデータである．同じアミノ酸配列のペプチドに由来する 同じLC/MS/MSのデータに含まれるスペクトルデータで あっても，12のクエリーがスペクトルライブラリーに よって同定されないデータであった.

スペクトルデータが収録されていた断片ペプチドから取
得されたデータにもかかわらず，スペクトルライブラリー によって同定されなかったデータは，試料由来のプロダク トイオンスペクトルとスペクトルライブラリーに収録され たスペクトルデータのプロダクトイオンの種類や強度のパ ターンの合致度が低かったことが考えられる。プロトン付 加分子の衝突誘起解離 (collision-induced dissociation: CID) によって得られたプロダクトイオンスペクトルのパターン は, 電子イオン化によって得られる分子イオンとそのフラ グメントイオンが観測されるマススペクトルと比較すると 再現性が低いことが知られている。このことは，残念なが ら，電子イオン化マススペクトルのスペクトルライブラ リーを利用したライブラリーサーチとは異なり，MASCOTのペプチドライブラリーサーチでは, 同じアミノ酸 配列に由来するすべてのクエリーを必ずしも同定できるわ けではないことを示している。

\section{5 異なる化学修飾トリプシンスペクトルライブラ リーを利用したゲル内消化物中の想定外自己消化断片 ペプチドの同定}

同定されなかった 15 種の断片ペプチドのうち 11 種類は “Trypsin_Promega_SG1”に収録されておらず，残りの 4 種類はスペクトルデータが収録されていたにもかかわら ず同定されなかった。

それゆえ，同じアミノ酸配列のペプチドのデータであっ ても“Trypsin_Promega_SG1”に収録されたデータとは異 なるスペクトルパターンのデータが収録されることや， “Trypsin_Promega_SG1”に収録されなかったペプチドの データが収録されることを期待して，試料の調製方法や分 析条件を変えずに，別途調製した試料を分析することに よって化学修飾トリプシン自己消化断片ペプチドの LC/

\begin{tabular}{|c|c|}
\hline Query & Start - End \\
\hline 1458 & $19-27$ \\
\hline $\mathbb{U}^{\prime 1459}$ & $19-27$ \\
\hline$\triangle 1280$ & $40-48$ \\
\hline$₫ 4262$ & $58-74$ \\
\hline$\triangle 4263$ & $58-74$ \\
\hline$\varangle 4264$ & $58-74$ \\
\hline $\mathbb{\top}^{4} \underline{4265}$ & $58-74$ \\
\hline$\sigma^{4} \underline{434}$ & $58-75$ \\
\hline đ4 4588 & $58-77$ \\
\hline$₫ 4592$ & $58-77$ \\
\hline đ゙ 4593 & $58-77$ \\
\hline đ4 4597 & $58-77$ \\
\hline$₫ 4601$ & $58-77$ \\
\hline$₫ 4590$ & $58-77$ \\
\hline đ゙́4994 & $58-77$ \\
\hline ષ゙4 $\underline{4585}$ & $58-77$ \\
\hline 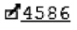 & $58-77$ \\
\hline đ゙ 4587 & $58-77$ \\
\hline$₫ 4589$ & $58-77$ \\
\hline đ゙ $\underline{4591}$ & $58-77$ \\
\hline ه゙4595 & $58-77$ \\
\hline đ゙ 4596 & $58-77$ \\
\hline$₫ 4598$ & $58-77$ \\
\hline đ゙ 4599 & $58-77$ \\
\hline$\triangle 4600$ & $58-77$ \\
\hline đ゙ 4608 & $58-77$ \\
\hline $\mathbb{đ}^{4} \underline{609}$ & $58-77$ \\
\hline শ゙ 4604 & $58-77$ \\
\hline$₫ 4 \underline{4605}$ & $58-77$ \\
\hline $4 \underline{4630}$ & $58-77$ \\
\hline$₫ 4631$ & $58-77$ \\
\hline
\end{tabular}

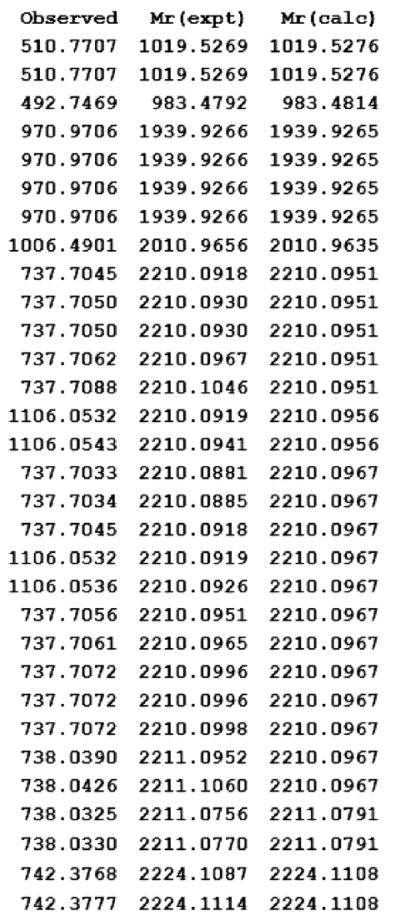

\begin{tabular}{rrrlrr}
\multicolumn{1}{rl}{ pPm } & M & Score & Source & Expect \\
-0.65 & 0 & 731 & SL & $1.7 \mathrm{e}-05$ \\
-0.65 & 0 & 532 & SL & 0.049 \\
-2.23 & 0 & 688 & SL & $9.5 \mathrm{e}-05$ \\
0.034 & 0 & 785 & SL & $1.9 \mathrm{e}-06$ \\
0.034 & 0 & 762 & SL & $4.9 \mathrm{e}-06$ \\
0.034 & 0 & 761 & SL & $5.1 \mathrm{e}-06$ \\
0.034 & 0 & 673 & SL & 0.00017 \\
1.00 & 0 & 742 & SL & $1.1 \mathrm{e}-05$ \\
-1.52 & 0 & 581 & SL & 0.0069 \\
-0.94 & 0 & 727 & SL & $2 \mathrm{e}-05$ \\
-0.94 & 0 & 824 & SL & $4.1 \mathrm{e}-07$ \\
0.71 & 0 & 685 & SL & 0.00011 \\
4.28 & 0 & 818 & SL & $5.2 \mathrm{e}-07$ \\
-1.65 & 0 & 858 & SL & $1 \mathrm{e}-07$ \\
-0.66 & 0 & 851 & SL & $1.4 \mathrm{e}-07$ \\
-3.90 & 0 & 74 & AA & $1.6 \mathrm{e}-07$ \\
-3.74 & 0 & 30 & AA & 0.0044 \\
-2.25 & 0 & 27 & AA & 0.0096 \\
-2.19 & 0 & 122 & AA & $2.6 \mathrm{e}-12$ \\
-1.85 & 0 & 92 & AA & $2.6 \mathrm{e}-09$ \\
-0.76 & 0 & 49 & AA & $5.4 \mathrm{e}-05$ \\
-0.093 & 0 & 71 & AA & $3.7 \mathrm{e}-07$ \\
1.31 & 0 & 31 & AA & 0.0039 \\
1.31 & 0 & 31 & AA & 0.0039 \\
1.40 & 0 & 46 & AA & 0.00012 \\
452 & 0 & 37 & AA & 0.00085 \\
457 & 0 & 50 & AA & $4.8 \mathrm{e}-05$ \\
-1.60 & 0 & 769 & SL & $3.7 \mathrm{e}-06$ \\
-0.94 & 0 & 737 & SL & $1.3 \mathrm{e}-05$ \\
-0.97 & 0 & 879 & SL & $4.5 \mathrm{e}-08$ \\
0.26 & 0 & 802 & SL & $9.8 \mathrm{e}-07$ \\
& & & &
\end{tabular}

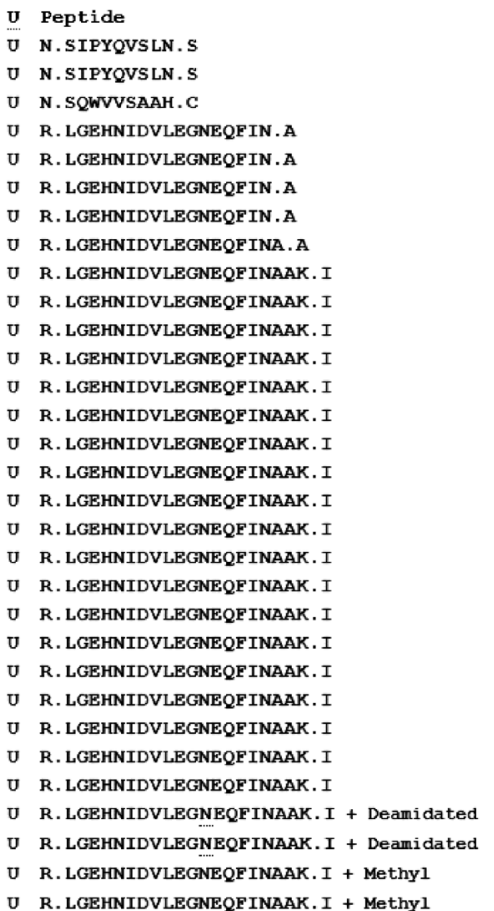

Fig. 2. A part of identified peptide data matching TRYP_PIG in the MASCOT search of the LC/MS/MS data obtained from an in-gel digest, using Search Strategy C. 
MS/MSデータを取得し, “Trypsin_Promega_SG1”と同じ 方法でスペクトルライブラリー “Trypsin_Promega_SG2” を作成した。スペクトルライブラリー“Trypsin_Promega_ SG2”を得るためのLC/MS/MS データは, 試料の調製日, LC/MS/MS の分析を実施した日が異なるだけで, 同じPromega Corporationの Sequence Grade Modified Trypsinの製 品を調製し，分析したデータである.

Search Strategy Cの “Trypsin_Promega_SG1” に換えて “Trypsin_Promega_SG2”を用いた検索（Table 3, Search Strategy D）を行ったところ, Search Strategy Cと同様, Search Strategy Bで同定されたすべての断片ペプチドを同 定することはできなかった（Table 4, Search Strategy Dの 列). 同定された断片ペプチドの中にはSearch Strategy Cの 検索で同定されなかった断片ペプチドがある一方, Search Strategy Cの検索で同定されたにもかかわらず, Search Strategy Dの検索では同定されない断片ペプチドもあった.

3.6 複数の化学修飾トリプシンスペクトルライブラ リーを併用したゲル内消化物中の想定外自己消化断片 ペプチドの同定

次に, “Trypsin_Promega_SG1” と “Trypsin_Promega_SG2” を併用した検索（Table 3, Search Strategy E）を行ったとこ ろ, Search Strategy Cでは同定できなかった 8 種類の断片 ペプチドを追加で同定することが可能となった（Table 4, Search Strategy Eの列)。この結果は, スペクトルライブラ リーを利用して, 化学修飾トリプシンの自己消化断片ペプ チドをできる限り多く同定するためには，異なる調製，異 なる分析によって作成した複数のスペクトルライブラリー を併用した検索を行うことが望ましいことを示している.

3.7 スペクトルライブラリー“PRIDE_contaminants”を 利用したゲル内消化物中の想定外自己消化断片ペプチ ドの同定

MASCOTではデフォルトのスペクトルライブラリーとし て“PRIDE_contaminants”14)を利用できる. 本研究で作成 した “Trypsin_Promega_SG1”や“Trypsin_Promega_SG2” に換えて“PRIDE_contaminants”を利用した検索（Table 3, Search Strategy F）を行ったところ 14 種類のトリプシン 自己消化断片ペプチドを同定することができた（Table 4, Search Strategy Fの列)．そのうち，“PRIDE_contaminants” を使用せずとも同定可能な特異的な加水分解によって生じ た断片ペプチドは8種類であり, “PRIDE_contaminants” を使用したことによって同定できた断片ぺプチドは6種類 のみであった. 同じLC/MS/MSデータを用いた検索で あったが, “Trypsin_Promega_SG1”と“Trypsin_Promega_SG2”を併用した検索（Search Strategy E）と比較する と, 同定された断片ペプチドは35種類少なく, 化学修飾 トリプシン由来の想定外自己消化断片ペプチドを検出する ためのスペクトルライブラリーとしては不十分である. “PRIDE_contaminants” はトリプシンの消化断片ペプチド のみが含まれているトリプシンに特化したスペクトルライ ブラリーではなく, またメチル化などの修飾基を考慮した 同定結果から作成されたものではない.
配列データに対する検索も並行して行われる断片ペプチ ドLGEHNIDVLEGNEQFINAAK（58-77）については18 のクエリーがマッチしていると判断されたが，スペクトル ライブラリーによって同定されたクエリーはNo. 4592 のみ であった。

\section{4. 考察}

\section{1 想定外の断片ペプチドが存在する理由}

Supporting Information 1 と Table 4 にリストアップされ たほとんどの断片ペプチドは, Search Strategy Aのような 通常の検索条件では検索対象外となる下記の特徵を有する ペプチドである。

1）モノメチル化もしくはジメチル化Lys残基を含んだ断 片ペプチド

2）Asn残基もしくは Gln残基の脱アミド化, Met残基の酸 化, Trp残基からキヌレニン残基への変換によって生じた 断片ペプチド（Met残基の酸化については検索対象に加え られることも多い)

3） Lys-X, Arg-X以外のペプチド結合が加水分解される非 特異的な酵素反応によって生成した断片ペプチド

この中には自己消化を防ぐ目的で導入されたモノメチル 化 Lys 残基，もしくはジメチル化Lys残基のC末端側ペプ チド結合が加水分解されたことによって生じた断片ぺプチ ドも存在していた.

4） $\alpha$-アミノ基がメチル化された断片ペプチド

ブタトリプシン分子は 1 本のポリペプチド鎖によって構 成されているモノマーである．1本のポリペプチド鎖の状 態であれば，成熟型トリプシンの $\mathrm{N}$ 末端である $\mathrm{I}^{9}$ 以外のす べての $\alpha$-アミノ基は, 試料タンパク質の断片化の工程が開 始されるまではポリペプチド鎖中でペプチド結合を形成し ている。それにもかかわらず $\mathrm{I}^{9}$ 以外の, トリプシンのペプ チド主鎖を構成していたはずの $\alpha$-アミノ基がメチル化され ている断片ペプチドが同定されたことは，メチル化処理前 に当該 $\alpha$-アミノ基がフリーになっていた形跡であり，この 位置のペプチド結合がメチル化処理以前に自己消化によっ てすでに加水分解されていたことを示している. Supporting Information 1 と Table 4 に示されている $\mathrm{V}^{108}$ の-アミノ 基がメチル化された断片ペプチドが検出されることは知ら れているが6),8), Supporting Information 1 には ${ }^{58} の \alpha-ア$ ミノ基がメチル化された断片ペプチドがリストアップされ ている. $\mathrm{L}^{58}, \mathrm{~V}^{108}$ はともにメチル化されない $\operatorname{Arg}$ 残基が寄 与するペプチド結合が加水分解されて生じる断片ペプチド の $\mathrm{N}$ 末端である。

Supporting Information 1 のリストには $\mathrm{A}^{75}, \mathrm{~A}^{76}, \mathrm{~K}^{77}, \mathrm{D}^{90}$, $\mathrm{L}^{95}$ の $\alpha$-アミノ基がメチル化された断片ペプチドが存在し ている，しかし，著者らはこれらのメチル化はソフトウェ アの誤同定であると判断した. $\mathrm{A}^{75}, \mathrm{~A}^{76}, \mathrm{~K}^{77}$ の-アミノ基 （N-term）がメチル化されていると判断されたすべてのス ペクトルデータのプリカーサーイオンの観測質量は，同じ アミノ酸配列で $\mathrm{K}^{77}$ のE-アミノ基がジメチル化された断片 ペプチドの計算質量の設定誤差範囲内であった。同じアミ 
ノ酸配列で $\mathrm{K}^{77}$ がジメチル化された断片ペプチド由来のイ オンから取得されたプロダクトイオンスペクトルパターン の微細な差異によって，ソフトウェアが判断する修飾基の 位置が変化したと考えられる。 $\mathrm{D}^{90}, \mathrm{~L}^{95}$ の $\alpha$-アミノ基のメ チル化についても同様に $\mathrm{K}^{97}$ がジメチル化された断片ペプ チドから取得されたスペクトルデータを誤同定した結果だ と思われる。

「化学修飾トリプシンスペクトルライブラリー」作成の 目的は, 修飾基の解析を正確に行うことではなく, 化学修 飾トリプシン断片ペプチドに由来するスペクトルデータが 別のタンパク質由来の断片ペプチドとして䛊同定されるこ とを防ぐことである。修飾基の同定に関しては適切ではな いが, 化学修飾トリプシン由来の断片ペプチドを同定して いることは誤りではないことから，作成の目的を満たして おり，ライブラリーに収録されていること自体は問題ない と判断した。

\section{$4.2 S$-カルバミドメチル化システイン残基を含む断片 ペプチド}

通常の検索方法（Search Strategy A）による検索結果に おいても, ゲル内消化物からは 3 種類の $S$-カルバミドメチ ル化Cys残基を含んだトリプシン自己消化断片ペプチドが 検出されている（Table 4). ゲル内還元 $S$-カルバミドメチ ル化の工程は, トリプシンを添加して消化を開始する前に 行われ，トリプシンのCys残基をS-カルバミドメチル化す る目的で行われてはいない.しかしながら, 筆者のこれま での経験でも，S-カルバミドメチル化Cys残基を含むトリ プシンの断片ペプチドが検出される分析例が多い. ゲル内 還元 $S$-カルバミドメチル化とトリプシンによる断片化は同 じチューブ内で行われることから, チューブの器壁やゲル 中に残存していたモノヨードアセトアミドによってトリプ シンのCys残基がS-カルバミドメチル化されたことが推定 される. 今回, スペクトルライブラリーを作成するために 分析に供した試料は還元 $S$-カルバミドメチル化処理を施さ ない試料から調製されており，S-カルバミドメチル化 Cys 残基を含んだ断片ぺプチドは含まれていない. Search Strategy Bでは, S-カルバミドメチルCys残基を含み，か つ非特異的な切断によって生成した断片ペプチドが数多く 同定されている。その中にはジメチル化された断片ペプチ ドも存在している.これらの断片ペプチドは今回作成した スペクトルライブラリーを用いても同定することはできな い.S-カルバミドメチル化Cys残基を含んだ想定外自己消 化断片ペプチドを同定するためには，還元 $S$-カルバミドメ チル化処理後の化学修飾トリプシン自己消化断片ペプチド のスペクトルライブラリーを作成し, 未処理の試料のスペ クトルライブラリーと併用した検索を行う必要がある.

ブタトリプシンは 12 の Cys残基を有しており, $\mathrm{C}^{15}-\mathrm{C}^{145}$, $C^{33}-C^{49}, C^{117}-C^{218}, C^{124}-C^{191}, C^{156}-C^{170}, C^{181}-C^{205}$ の6つのジ スルフィド結合を形成している. ゲル内消化物の試料中に は, S-カルバミドメチル化Cys残基を含んだトリプシンの 断片ペプチドは存在しているが, あくまでも副産物であ り, トリプシンのすべてのCys残基を $S$-カルバミドメチル
化するような処置が施されているわけではない.したがっ てジスルフィド結合で架橋されたままの断片ペプチドも試 料中に存在している ${ }^{8)}$. ジスルフィド結合を有する断片ぺ プチドの中にも，メチル化されたLys残基等を含む断片ぺ プチドが存在することが予想される．複雑になるため「3. 結果」にデータを示してはいないが，筆者らはスペクトル ライブラリー“Trypsin_Promega_SG1”を作成したデータ 中に, $C^{156} と C^{170}$ で架橋された断片ペプチドAPVLSDSSCK (148-157), SSYPGQITGNMICVGFLEGGK（158186），ジスルフィド結合のスクランブリングによって生じ たと推定される $\mathrm{C}^{117}$ と $\mathrm{C}^{124}$ が分子内架橋された断片ペプチ ドSCAAAGTECLISGWGNTK（116-133），およびその $\mathrm{K}^{113}$ がジメチル化された断片ペプチドにマッチするデータ が含まれている結果を得ている。ジスルフィド結合を考慮 した化学修飾トリプシン断片ペプチドのスペクトルライブ ラリーを作成し，併用して検索を行った結果，本研究で用 いたゲル内消化物の試料中に $C^{117} と C^{124}$ が分子内架橋され たSCAAAGTECLISGWGNTK（116-133）とその $\mathrm{K}^{113}$ がジ メチル化された 2 種類の断片ペプチドを同定することが可 能となった。

\section{3 脱アミド化された Asn残基，Gln残基を含む断片 ペプチド}

トリプシン自己消化断片ペプチドにはAsn残基, Gln残 基の脱アミド化によって生成したペプチドが多数同定され ている. 脱アミド化は塩基性条件下で起こりやすい非酵素 的な修飾であり ${ }^{15)}$, タンパク質変性の一種である. 化学 修飾トリプシンの製品化の工程や, 弱塩基性条件下で行わ れる消化の過程で脱アミド化が起こっていると予想され る.脱アミド化によってペプチドの質量は約 $1 \mathrm{Da}$ 増加す ることから，ペプチド中の脱アミド化の有無はプリカー サーイオンの観測質量で識別することは容易である。しか しながら，当該断片ペプチド中にAsn残基や Gln残基が複 数存在している場合は，観測されたプロダクトイオンスペ クトルから脱アミド化が起きたアミノ酸残基を正確に特定 することが困難なことも多い. Search Strategy Bでは, C 末端ペプチドYVNWIQQTIAAN（220-231）の Q ${ }^{225}$ が脱ア ミド化されたペプチドが同定されているが, Search Strategy Dでは同じスペクトルデータ（クエリー）が， $\mathrm{N}^{222}$ が 脱アミド化されたペプチドとして同定されている，スペク トルライブラリー “Trypsin_Promega_SG1”と“Trypsin_ Promega_SG2”には Q 225 が脱アミド化されたと判断され た断片ペプチドYVNWIQQTIAANのデータが収録されて いないためである. Search Strategy Bによる検索において も, “Trypsin_Promega_SG1” や“Trypsin_Promega_SG2” を作成するために行った検索においても，脱アミド化され た断片ペプチドとしての同定に誤りはないと考えられる が，表示された脱アミド化アミノ酸残基の位置が正確では ない可能性もある. しかし, 脱アミド化が起こっている化 学修飾トリプシン由来断片ペプチドを同定できることが重 要であり, 具体的な修飾部位の正確性を求める必要はない と考える。 


\section{4 プロダクトイオンスペクトルの再現性}

エレクトロスプレーイオン化法等によって生成されるプ ロトン付加分子をプリカーサーイオンとする CID プロダ クトイオンスペクトルのパターンは, ガスクロマトグラ フィ一質量分析法において得られる電子イオン化マススペ クトルに比べて再現性が低いことが知られている。本研究 においても，同じ配列をもった断片ペプチドに由来するス ペクトルデータがスペクトルライブラリーに存在している にもかかわらず，同定することができなかった例もあっ た. 別の測定結果から作成したスペクトルライブラリーを 併用することで, 完全ではないが補完することが可能であ ることを示すことができた，LC/MS/MSで取得されたスぺ クトルデータのライブラリーサーチを行う場合は, 化学修 飾トリプシンの自己消化物に限らず，同じ試料であっても 複数のライブラリーを作成し, 併用することが望ましいと 考える. 本研究では同じ調製方法, 同じ測定方法で取得し た異なるスペクトルデータを利用したが，導入する試料量 やLCの溶出条件など, 条件を変化させて取得した複数の スペクトルデータから作成することが望ましいと考える.

筆者らは検証した 5 社の化学修飾トリプシン市販品のす ベてが，製品の段階ですでに部分的に自己消化されている ことを示すデータをドデシル硫酸ナトリウムポリアクリル アミドゲル電気泳動によって得ている. しかも自己消化の 程度はメーカーによって異なっていた. 自己消化の進行具 合が異なれば，生じる断片ペプチドの種類や量に違いが生 じることが考えられる．化学修飾トリプシン自己消化断片 ペプチドのスペクトルライブラリーを利用する場合は, CID プロダクトイオンスペクトルの再現性の問題もあるこ とから, 利用している商品のデータを, 利用しているLC/ MS/MS 装置で取得, 作成した複数のライブラリーを利用 することが望ましい，本研究で作成した 2 種類のスペクト ルライブラリーのスペクトルデータ数は172（SG1）と 133 （SG2）であり，この程度のスペクトルライブラリーを複 数併用しても検索時の負荷はほとんど変わらない.

\section{5 化学修飾トリプシンはプロテオミクスのための最} 適なエンドペプチダーゼなのか ?

トリプシンのメチル化処理によって自己消化の反応速度 は抑制されたかもしれないが完全に阻害されたわけではな い. メチル化処理自体も完全ではなく, 未修飾, モノメチ ル化, ジメチル化の 3 種類の Lys残基が存在している. 加 えて Lys 残基での miss cleavageが起こる確率を上げている ことから, メチル化処理を行うことによって, 自己消化断 片ペプチドの種類を何倍にも増加させている，化学修飾が 施されていないトリプシンの自己消化断片ペプチドを分析 したとしても, Supporting Information 1のような多種多様 な断片ペプチドは得られない. 自己消化を抑制させること は, タンパク質量当たりの反応速度である比活性を上げる 利点はあるかもしれない. しかし化学修飾トリプシンを用 いることは，非修飾トリプシンを用いることと比較して， 分析試料中の試料以外のペプチドの種類を増やす状態を招 いている. LC/MS/MSを用いたショットガンプロテオミク
スでは，試料中に存在するすべてのペプチドのスペクトル データが取得されているわけではない。そのため，トリプ シン自己消化断片ペプチドの種類が多ければ多いほど，本 来の目的である試料ペプチドのイオン化やプロダクトイオ ンスペクトルデータの取得の機会を抑制することになる。 化学修飾が施されていないトリプシン製品を使用して消化 を行った場合，特定の自己消化断片ペプチドの量は確実に 増加することが予想されるが，断片ペプチドの種数は減少 する．プロテオミクスにおけるトリプシンの有用性は疑う 余地はないと思われるが，化学修飾の有無に関しては再検 討する意義はあるのではないだろうか.

\section{6 擬陽性を防ぐために}

質量確度の高い質量分析計を用いた場合，自己消化断片 ペプチド由来のデータが他のタンパク質由来の断片ペプチ ドに䛊同定される確率はそれほど高くはないと思われる. しかし, FDR（false positive rate）を求める際, decoyデー タベースを対象とした検索が行われるが，存在しないはず の decoy配列に一定の割合でマッチするデータが存在して いる. 同様に, 通常の検索条件で同定されないトリプシン 自己消化断片ペプチド由来のデータが他のタンパク質由来 の断片ペプチドに䛊同定されることも起こりえる.

質量分析法とデータベース検索を利用するタンパク質同 定において，何種類ものペプチドが同定されることによっ てタンパク質が同定される場合，根拠とされるぺプチドの 中に1種類だけ誤同定されたペプチドが含まれていたとして も大きな問題にはならない.しかし 2,3 種類の少数の断片ぺ プチドのマッチによってタンパク質の存在を示す場合や, 翻訳後修飾の解析を目的とする場合は, 一つのスペクトル データの䛊同定は，䛊った結論を導き出す危険性を秘めて いる. 加えて，䛊った結果が示されたとしてもそれに気付 くことはかなり困難である．䛊同定の憂いをできる限り軽 減させるために，化学修飾トリプシン由来想定外断片スペ クトルライブラリーを併用した検索を行うことを勧める.

プロテオミクスやバイオ医薬品分析における LC/MS/MS では，膨大なマススペクトルデータが取得されているが, 実際にタンパク質の同定や品質管理に用いられているデー 夕はその一部であり，大部分は帰属されないまま無視され ている ${ }^{16)}$. しかし，イオンが発生している以上，無視さ れたマススペクトルデータを与えた化合物は必ず存在して いる．抗体医薬品に代表されるバイオ医薬品の分析におい ては，帰属されないデータは不純物や医薬品本体の変化を 反映したペプチドに由来する可能性もあり，多くのスペク トルデータを未帰属のまま放置することは品質管理上，好 ましい状態ではない，帰属されないデータの中には試料由 来, 溶媒由来, 環境由来, 分析機器由来等, さまざまな原 因があると思われるが，可能な限り取得されたマススペク トルデータを帰属することを目指すべきである。それに よって, プロテオミクスでは擬陽性や䛊同定を減少させ, バイオ医薬品の分析においては，想定外の不純物の存在や 医薬品の変性を迅速に検知できる品質管理法が可能になる と考える. 


\section{文献}

1) J. V. Olsen, S. E. Ong, and M. Mann, Mol. Cell. Proteomics, 3, 608 (2004).

2) J. V. Olsen and M. Mann, Proc. Natl. Acad. Sci. U.S.A., 101, 13417 (2004)

3) J. M. Burkhart, C. Schumbrutzki, S. Wortelkamp, A. Sickman, and R. P. Zahedi, J. Proteomics, 75, 1454 (2011).

4) M. M. Vestling, C. M. Murphy, and C. Fenselau, Anal. Chem., 62, 2391 (1990)

5) W. A. Harris, D. J. Janecki, and J. P. Reilly, Rapid Commun. Mass Spectrom., 16, 1714 (2002).

6) K. F. Medziharadszky, Meth. Enzymol., 405, 50 (2005).

7) M. Schittmayer, K. Fritz, L. Liesinger, J. Griss, and R. BirnerGruenberger, J. Proteome Res., 15, 1222 (2016).

8) UCSF Mass Spectrometry Facility, "Trypsin Autolysis Products" in ProteinProspector, 〈http://prospector.ucsf.edu/prospector/html/misc/trypsin.htm $\rangle$.

9) P. Picotti, R. Aebersold, and B. Domon, Mol. Cell. Proteomics,
6, 1589 (2007).

10） J. Rodriguez, N. Gupta, R. D. Smith, and P. A. Pevzner, J. Proteome Res., 7, 300 (2008).

11) J. Bunkenborg, G. Espadas, and H. Molina, J. Proteome Res., 12, 3631 (2013).

12) P. D. Gershon, J. Proteome Res., 13, 702 (2014).

13) M. C. Chambers, B. Maclean, and P. Mallick, Nat. Biotech., 30, 918 (2012).

14） J. Griss, Y. J. M. Foster, H. Hermjakob, and J. A. Vizcaíno, Nat. Methods, 10, 95 (2014).

15) P. Hao, Y. Ren, A. Datta, J. P. Tam, and S. K. Sze, J. Proteome Res., 14, 1308 (2015).

16) J. Griss, Y. Perez-Riverol, S. Lewis, D. L. Tabb, J. A. Dianes, N. Del-Toro, M. Rurik, M. W. Walzer, O. Kohlbacher, H. Hermjakob, R. Wang, and J. A. Vizcaíno, Nat. Methods, 13, 651 (2016).

Key words: Trypsin, Methylation, Autolysis, Database search, Spectral library, Protein identification 